\title{
Penggunaan Metode Content Analysis dalam Penelitian Hadis
}

\author{
Andi Rahman ${ }^{1}$
}

\begin{abstract}
To determine the authenticity of hadith, we need to analyze its chain of transmission and its content. The analysis of the chain of transmission is conducted through the data collection in the literature of tarājum al-ruwāt, by analyzing the concept used in sanad criticism.

Among the critique of hadith, some scholars used a concept generally used by others, but they understand it differently. Others use special concept not usually used by others, without explaining what they mean by that concept. There are also others who explain the biography of the hadith transmitters, without explaining their qualities, Al-Bukhàri $(d .265 \mathrm{H})$ is among the ciritique of hadith who use these three concepts.

This article, using content analysis methodology, tries to analyze and understand these three concepts.
\end{abstract}

\begin{abstract}
Abstrak
Untuk mengetahui keotentikan sebuah hadis, kita perlu meneliti sanad dan matan hadis tersebut. Penelitian sanad hadis, dilakukan melalui data yang terkoleksi di literatur tarājum al-ruwāt (biografi perawi hadis), dengan membaca dan menganalisis istilah-istilah yang digunakan dalam aktivitas kritik sanad.

Di antara para kritikus hadis, ada sarjana yang menggunakan istilah yang telah dipakai secara umum namun dimaknainya secara berbeda. Ada yang menggunakan istilah khusus yang tidak digunakan oleh kritikus lain, tanpa menjelaskan apa maksud dari istilah tersebut. Ada juga yang menjelaskan biografi perawiperawi hadis, namun tidak menyatakan apa-apa terkait kualitas
\end{abstract}

\footnotetext{
${ }^{1}$ Dosen Institut PTIQ Jakarta. E-mail: andiwowo@yahoo.com.
} 
mereka. Di antara para kritikus hadis yang menggunakan tiga macam istilah ini adalah al-Bukhärì (w. 256 H.).

Tulisan ini, dengan menggunakan metodologi content analysis, mencoba menganalisis dan memberikan pemaknaan tiga macam istilah di atas.

Keywords: Muqārib al-ḥadith, munkar al-hadith, sakatū 'anh, thiqah, pemalsuan hadis.

Sebagai data kesejarahan, hadis memiliki problematika keotentikan. Sejarah mencatat bahwa pemalsuan hadis (fabrikasi) sudah muncul di masa shahabat, tepatnya setelah peristiwa pembunuhan terhadap khalifah Uthmān bin 'Affān, di mana orang yahudi dan munafiq secara massif berhasil menginfiltrasi umat Islam dan menghembuskan isu-isu dan propaganda bohong serta black campaign terhadap khalifah di Madinah. ${ }^{2}$

${ }^{2}$ Menurut sebagian orang, bibit kemunculan hadis palsu sudah ada di zaman Rasulullah seiring dengan mulai maraknya aktivitas-aktivitas "bawah tanah" yang dilakukan oleh orang-orang yahudi yang jahat dan orang-orang munafik.

Salah satu hadis yang dijadikan dalil adanya pemalsuan hadis di masa Rasulullah, adalah riwayat Ibn al-Jauzi melalui beberapa jalur periwayatan (turuq) tentang seorang laki-laki yang mendatangi daerah pinggiran kota Madinah (fi jānib al-Madinah), dan berseru, "Sesungguhnya Rasulullah memerintahkanku untuk mengurusi kalian, harta kalian, dan segala-galanya (an ậkum fikum bi ra'yi wa fi amwälikum wa fi kadha wa fi kadha)". Laki-laki ini dulunya, di masa jahiliyah, pernah melamar seorang gadis dari daerah tersebut, namun ditolak. Ia bergeming untuk tetap menikahi perempuan tersebut. Merasa dibohongi, masyarakat setempat melapor perbuatan laki-laki ini kepada Rasulullah. beliau bersabda, "Musuh Allah ini telah berdusta" (kadhaba 'aduwwullāh). Rasulullah lalu memerintahkan dua orang shahabat untuk menangkap laki-laki tadi seraya menginstuksikan, "jika masih hidup, penggallah lehernya, dan jika sudah mati bakarnya jasadnya". Ternyata laki-laki tadi sudah mati akibat disengat kalajengking, lalu dibakarlah jasadnya". Hadis ini juga dikutip oleh al-Tahạāi yang meriwayatakannya melalu dua jalur.

'Abdurrahmān bin 'Ali bin Muhammad al-Jawzī (Ibn al-Jawzī), al-Mawḍu'āt (Madinah: al-Maktabah al-Salafiyah, 1968), cet. I, vol. I, 55-56.

Aḥmad bin Muhammad al-Ṭahāwī, Sharḥ Mushkil al-Āthār (Muassasah alRisālah, ttp, 1494), cet. I, vol. I, 352.

Madar (yang dalam bahasa Joynboll disebut commont link) hadis tersebut adalah Șālih bin Ḥayyān yang disepakati sebagai perawi dhaif. Tidak ada jalur lain, sehingga kita sebut riwayat ini fard (single), dan hadis fard kebanyakan kualitasnya dhaif. AlBukhāri sendiri menilai perawi ini dengan ungkapan "fihi nazar" yang artinya perawi ini sangat dhaif dan tidak halal hadisnya diriwayatkan.

102 Vol. 3, No. 1, (2014) 
Maraknya pemalsuan hadis, mendorong para ulama untuk lebih intensif melakukan penjagaan hadis. Pada masa awal penjagaan ini dilakukan hanya sebatas menghafal matan-matan hadis. Seiring dengan perjalanan waktu para

Muhammad bin Ismā'il al-Bukhārī, al-Tārikh al-Kabīr (Hedarabad: Dār alMa'ārif al-'Uthmāniyyah, tth), vol. IV, 275.

'Abdurraḥmān bin Muhammad (Ibn Abū Hạatim), al-Jarh wa al-Ta'dîl (Hedarabad: Dār al-Ma'ārif al-'Uthmāniyyah, 1952), cet. I, vol. IV, 398.

Hipotesa tentang adanya pemalsuan hadis di masa Rasulullah, juga didasarkan beberapa argumentasi berupa kemunculan nabi-nabi palsu semisal Musaylamah alKadhdhāb. Orang-orang yang di masa Rasulullah mengaku sebagai nabi ini, menganggap ucapan dan perbuatannya sebagai sumber ajaran Agama. Status mereka sebagai nabi palsu, menegaskan bahwa ucapan merekapun secara otomatis dilabeli hadis palsu.

Kemudian, adanya hadis mutawatir yang isinya ancaman siksa neraka bagi siapapun yang membuat kedustaan atas nama Rasulullah (man kadhdhaba 'alayya muta'ammidan falyatabbawa' maq'adahu min a-nār) dipahami sebagai bentuk reaksi Rasulullah atas pemalsuan hadis yang sudah ada dan diketahui oleh beliau.

Namun pendapat yang populer dan valid adalah bahwa hadis palsu baru muncul pasca pembunuhan khalifah Uthmān bin 'Affān. Hal ini diakibatkan luasnya daerah yang telah dibebaskan oleh umat Islam di masa khalifah Umar bin al-Khatțāb, yang tidak mampu dikontrol dengan baik oleh khalifah ketiga ini. Pada masa-masa ini, orang-orang munafik mulai berani bergerak di "atas tanah". Mereka tidak sungkan lagi menyerukan pembangkangan terhadap khalifah di Madinah, dan mereka tidak takut membuat hadis palsu untuk mendukung propaganda mereka.

Pada masa akhir kepemimpinan khalifah 'Uthmān inilah, benih-benih sekte/mazhab semisal Shī' ah, Khawārij, dan Mu'tazilah muncul dan berkembang.

Hadis yang berisi ancaman pemalsu hadis (man kadhdhaba 'alayya muta'ammidan...) dipahami bukan sebagai reaksi adanya kegiatan pemalsuan hadis, namun sebagai peringatan untuk umat di masa datang agar tidak berdusta atas nama Rasulullah. Yang demikian ini termasuk kategori "tanabbuāt" atau prediksi masa depan yang diketahui oleh Rasulullah berdasarkan wahyu.

Ibnu Sirin pernah menyatakan bahwa awalnya orang-orang tidak pernah bertanya tentang sanad hadis. Barulah ketika fitnah terjadi (yaitu peristiwa terbunuhnya khalifah Uthmān bin 'Affan), mereka mulai menanyakan sanad hadis; "Sebutkan dari siapa kamu mendengar hadis ini"

Maḥmūd al-Ṭaḥhān, Taysīr Muṣtalạh al-Hadith (Iskandariya: Markaz al-Hudā li al-Dirāāât, $1415 \mathrm{H})$, cet. VII, 11

Ada tiga alasan mendasar yang menegasikan kemungkinan terjadi pemalsuan hadis di masa Rasulullah. Pertama, para shahabat sangat mencintai Rasulullah. Sedemikian besar cinta itu sehingga mereka tidak akan tega dan berani melakukan halhal yang tidak disukai oleh Rasulullah, terutama berdusta atas nama beliau. Sebagian shahabat bahkan memiliki cinta yang cenderung menjadi obsesi di mana mereka berupaya untuk senantiasa meniru perilaku dan kebiasaan Rasulullah pada hal-hal yang sebenarnya berangkat dari sisi kemanusiaan beliau (bashariyah) dan tidak terkait dengan syariat Agama. Kedua, ada kontrol sosial yang sangat kuat di antara mereka sehingga setiap ada kejadian yang dianggap tidak sesuai dengan ajaran Rasulullah, mereka langsung bereaksi dan dengan lugas menentangnya. Ketiga, para shahabat mengetahui ancaman bagi pelaku pemalsuan hadis. Dalam banyak riwayat dikisahkan betapa mereka sangat takut melakukan dosa, walaupun yang dikategorikan sebagai dosa kecil. 
ulama tidak hanya melakukan pelestarian hadis, mereka juga melakukan penyaringan dan penyeleksian hadis-hadis yang dinilai tidak valid berasal dari Rasulullah. ${ }^{3}$ Pada abad kedua hijriyah, upaya penyeleksian hadis ini semakin intensif dilakukan seiring bertambah banyaknya hadis-hadis palsu yang muncul dan beredar di masyarakat. Selanjutnya, upaya melakukan uji otentisitas hadis menjadi kajian utama dalam penelitian hadis hingga sekarang. ${ }^{4}$

Sedari awal masa kodifikasinya, penelitian hadis lebih didominasi dengan penelitian atas sanad hadis. Hal ini berlanjut hingga sekarang di mana aktivitas pemalsuan hadis dan penyebaran hadis palsu semakin semarak. Penelitian atas sanad hadis artinya penelitian atas sosok-sosok perawi yang ada dalam sanad tersebut; Apakah ia 'ādil dan dengan dua cara: Observasi langsung dan kajian perpustakaan.

Maksud dari observasi di sini adalah bahwa peneliti hadis mendatangi subjek penelitiannya, yaitu tokoh perawi hadis yang akan ia teliti, untuk mendengarkan periwayatan hadisnya. Selanjutnya, ia meneliti tingkat keterpercayaan (thiqah) perawi tersebut dan bagaimana kualitas periwayatannya. Dari sini muncul cabang ilmu hadis yang khusus membahas hal ini yang kita kenal dengan rihlah fi talab al-ḥadith.

Jika observasi tidak bisa dilakukan, semisal sosok perawi yang ingin diteliti sudah wafat, maka penelitian dilakukan melalui kajian perpustakaan dengan membaca data biografi yang sudah ditulis dalam literatur taräjum alruwät, yang belakangan kita kenal dengan istilah ilm rijāl al-ḥadith.

Penelitian hadis, memang lebih dititikberatkan kepada penelitian sanadnya. Karena, secara aksiomatik, keterpercayaan kita terhadap kebenaran sebuah berita berbanding lurus dengan keterpercayaan kita terhadap orang/sumber yang menyampaikannya. Kajian atas matan hadis juga diperlukan,

${ }^{3}$ Upaya penyeleksian hadis sebenarnya sudah dilakukan oleh khalifah Abū Bakar dengan cara mu'āraḍah al-riwāyāt, di mana beliau hanya menerima hadis yang tidak diketahuinya dengan syarat hadis tersebut didengar atau disaksikan oleh dua orang shahabat. Jika hanya ada satu orang yang meriwayatkannya, Abū Bakar cenderung mengabaikannya. Ketelitian ini yang kemudian menjadikannya dijuluki nāṣir al-sunnah al-awwal.

MM Azami (Muhammad Muṣtafa al-A'zami), Manhaj al-Naqd 'Inda alMuhaddithīn (Saudi Arabia: Maktabah al-Kawthar, 1990), cet. III, 50.

4 Isu utama dalam diskursus hadis ada dua, otentisitas dan otoritas hadis. Otoritas hadis baru bisa didiskusikan setelah hadis itu dipastikan otentik, dalam artian hadis bisa dijadikan sumber hukum dan ajaran dalam Islam hanya jika kualitasnya shahih.

Andi Rahman, "Arus Utama Diskursus Hadis: Kajian Atas Otentisitas dan Otoritasnya Sebagai Hujjah,” dalam Jurnal al-Burhan vol. 16, no. 1, (2011), 185. 
namun ia bisa dilakukan hanya setelah sanadnya selesai diteliti dan dianggap memuat kejanggalan. ${ }^{5}$

Dalam penelitian sanad hadis, kita dapati ada istilah-istilah yang dipakai secara umum oleh nuqqād (para kritikus hadis), semisal: thiqah, thabat, sadūq, ḍa'ï, hujjah, matrūk dan waḍ̂a',. Istilah-istilah ini telah dikenal secara umum dan mudah dipahami oleh siapapun yang mempelajari ilmu kritik hadis. Namun ada juga istilah-istilah yang hanya digunakan oleh seorang kritikus, yang tidak digunakan oleh kritikus lain (Iștilāhăt li ashkhạs yanbaghỉ al-tawqīf 'alayhā). ${ }^{6}$ Sebagian dari istilah-istilah ini ada yang telah dijelaskan sendiri oleh orang yang menggunakannya, dan sebagian lainnya tidak.

Ketika ada istilah yang oleh penggunanya tidak dijelaskan maksudnya, maka akan muncul kerancuan pemahaman. Di sinilah kita perlu melakukan kajian untuk mengetahui apa arti dari istilah-istilah tersebut.

Salah satu kritikus hadis yang menjadi rujukan utama dalam penelitian hadis adalah Al-Bukhāri (w. 256 H.). Selain menulis kumpulan hadis-hadis shahih dalam kitab Sahihh-nya, beliau juga menulis kitab-kitab tentang biografi perawi hadis semisal al-Tärikh al-Kabīr. Al-Bukhāri menggunakan beberapa istilah yang tidak umum digunakan oleh kritikus hadis lainnya, atau menggunakan satu istilah umum namun dengan pemahaman yang berbeda, misalnya: Muqārib al-ḥadith, munkar al-ḥadith, laysa bi dhāka, hadha akthar, fulan sami'a min fulan (yang berbeda dengan rawā 'an fulān), sakatu 'anh, ahàdithuhu ma'rüfah, dan fỉhì nazhar-fï isnädihi nazhar-fï hadithishi nahzar. Menurut sebagian ulama, salah satu faktor penyebab hal ini adalah bahwa alBukhārì dinilai sebagai seorang kritikus hadis yang santun (lațîf al- 'ibārah fí al-

5 Kejanggalan ini disebut sebagai shadh. Kejanggalan dalam korpus hadis bisa terdapat di sanad dan di matan. Matan hadis dianggap janggal jika ia memuat informasi dan kandungan yang bertentangan dengan hadis lain atau bahkan dengan al-Qur'an. Ada dua teori yang mendasari diskursus ini; Pertama bahwa Rasulullah adalah orang yang paling mengetahui al-Qur'an, dan satu-satunya orang yang secara lugas dinyatakan memiliki mandat menjelaskan al-Qur'an (QS. al-Baqarah: 151, Alu Imran: 164, alJumu'ah: 2, al-Naḥl: 44 dan 64). Karenanya, mustahil jika Rasulullah mengucapkan hadis, atau melakukan perbuatan yang bertentangan dengan ajaran al-Qur'an. Kedua, adalah bahwa Rasulullah mendapatkan "pengawalan" wahyu yang memungkinkannya tidak melakukan kesalahan, termasuk inkonsistensi dalam menjelaskan ajaran Agama (QS. al-Najm: 3-5). Jika ada hadis yang bertentangan dengan hadis lain, tanpa bisa dikompromikan, maka terjadi kegagalan fungsi wahyu dalam mengawal misi nubuwah. Hal ini mustahil terjadi mengingat wahyu berasal dari Allah Yang Maha Sempurna, yang tidak mungkin melakukan kegagalan.

${ }^{6}$ Muḥammad bin 'Abdurrạ̣mān al-Sakhāwī, Fatḥ al-Mughìth (Kairo: Maktabah al-Sunnah, 2003), cet. I, vol. I, 105-106. 
tajrīh), karenanya dalam menilai cacat seorang perawi hadis (tajrịh) ia menggunakan istilah sendiri yang tidak digunakan oleh kritikus lain, atau menggunakan istilah yang sudah umum namun dimaknai dengan pemaknaan yang sedikit berbeda. ${ }^{7}$

Selain al-Bukhāri, masih ada kritikus hadis lainnya yang juga memiliki istilah sendiri dalam menilai seorang perawi, semisal Ibn Ma'in (w. 233 H.) dengan "lā ba'sa bihi" dan "lays bihi ba's", ${ }^{8}$ al-Shāfi'i (w. 204 H) dengan "man lā attahim”, dan Ibn Ḥajar (w. 852 H) dengan "maqbūl".

Mengetahui makna dari istilah-istilah ini menjadi sangat penting, mengingat kualitas sebuah hadis itu tergantung kualitas perawinya, dan untuk mengetahui kualitas seorang perawi kita perlu memahami makna dari istilahistilah yang digunakan dalam aktivitas kritik hadis.

Ada beberapa ulama mutaakhirin yang mencoba menjelaskan istilahistilah yang tersebut di atas. Namun di antara mereka masih ada perbedaan pendapat. Perlu kiranya dilakukan penelitian yang menjadi antitesa dari perbedaan tersebut, dan bisa dijadikan sebuah kesimpulan akhir. Berangkat dari pemaparan di atas, penulis bermaksud menggunakan metode content analysis untuk meneliti makna dari istilah-istilah, yang oleh penggunanya, tidak dijelaskan apa maksudnya.

Metode content analysis yang akan digunakan pada penelitian/tulisan ini berguna untuk mengetahui tiga hal: Pertama, istilah yang hanya digunakan oleh seorang kritikus hadis namun dia tidak menjelaskan maksudnya. Kedua, istilah yang secara umum telah digunakan oleh para kritikus hadis, namun oleh seorang kritikus digunakan untuk pemahaman yang berbeda. Ketiga, makna dari diamnya seorang kritikus hadis terhadap kualitas seorang perawi. ${ }^{9}$

7 Ismaì'ill bin 'Umar bin Kathīr, Ikhtisār 'Ulūm al-Hadith (Beirut: Dār al-Kutub al-'Ilmiah, tth.), cet. II, 106; Al-Sakhāwì, Fatḥ al-Mughìth, vol. II, 126

${ }^{8}$ Al-Sakhāwì, Fatḥ al-Mughìth, vol. I, 106

9 Perawi hadis yang tidak diberikan penilaian atas kualitas diri dan periwayatannya ada dua macam: Pertama, perawi yang memang tidak diketahui kualitasnya oleh siapapun, yang dalam disiplin ilmu hadis dirayah disebut majhūl atau jahālah. Kedua, perawi yang dengan sengaja atau tidak sengaja didiamkan dan tidak diberikan penilaian yang dikenal sebagai al-ruwāt al-masküt 'anhum. Untuk kategori kedua ini, diam dianggap sebagai sebuah penilaian. Al-Dhahabi (w. 748 H.) dalam ta'liq kitab al-Mustadrak karya al-Ḥākim al-Naysābūri (w. 405 H.), dan al-Bukhāri disebutsebut menjadikan diam sebagai "penanda" atas kualitas seorang perawi hadis (min alfaz al-jarh wa al-ta'dii)

106 Vol. 3, No. 1, (2014) 


\section{Kerangka Kerja Metode Content Analysis}

Content analysis atau analisis isi adalah metode penelitian teks yang awalnya dilakukan dengan melihat bentuk dan struktur teks itu sendiri. Metode content analysis membutuhkan pembacaan yang sistematis terhadap teks, gambar, dan simbol, tanpa perlu menggunakan perspektif dari orang yang menulisnya (atau menggambarnya). Penggunaan content analysis sebagai metode penelitian, baru muncul pada tahun 1941. Namun, pada abad ke-17 Gereja telah menggunakannya dalam aktivitas inkuisisi akibat banyaknya selebaran yang dinilai bertentangan dengan dogma gereja. ${ }^{10}$

Sebagian orang menyamakan content analysis dengan kritik matan yang secara operasional dalam bentuk sederhananya telah ada pada zaman Rasulullah. Namun sejatinya kedua metode ini berbeda di mana metode content analysis itu bersifat kuantitatif sementara metode kritik matan bersifat kualitatif.

Sebagai sebuah studi kuantitatif, content analysis marak digunakan para pengkaji komunikasi. Biasanya, pendekatan ini dipakai pada penelitian surat kabar, jurnal, buku dan acara televisi guna mengkaji seberapa banyak ruang yang disediakan untuk tema tertentu, seberapa sering kata-kata kunci muncul, dan sebagainya. ${ }^{11}$

Peter Burke menangkap adanya reaksi menentang penggunaan metode kuantitatif dalam kajian perilaku manusia (antropologi), namun, ia mengakui bahwa metode content analysis telah lama digunakan untuk menganalisis dokumen-dokumen sejarah. ${ }^{12}$

Berikut adalah cara kerja metode content analysis yang akan penulis gunakan dalam penelitian ini, yang telah diselaraskan dengan kekhasan yang ada dalam diskursus hadis:

1. Penulis menentukan istilah mana yang akan diteliti, yaitu: Muqārib alhadith, munkar al-hadith, dan "sukut". Ketiga istilah ini dinisbahkan (diasosiasikan) kepada al-Bukhārì

2. Istilah yang diteliti tersebut ditelusuri letaknya dalam kitab taräjum alruwāt (biografi perawi)

3. Penulis memilih perawi yang dinilai dengan istilah-istilah di atas. Pemilihan ini dilakukan secara acak (random) tanpa menggunakan pola apapun

${ }^{10}$ Klaus Krippendorff, Content Analysis: An Introduction to Its Methodology (London: Sage Publications Ltd, 2004), 3.

${ }_{11}$ Peter Burke, History and Social Theory, alih bahasa oleh Mestika Zed dan Zulfahmi, Sejarah dan Teori Sosial (Jakarta: Yayasan Pustaka Obor Indonesia, 2011), cet. III, 48.

${ }^{12}$ Peter Burke, History and Social Theory, 48. 
4. Ungkapan-ungkapan yang menyertai istilah-istilah tersebut dianalisis, baik yang sifatnya menjelaskan (ziyādah al-bayān) maupun yang menegaskan (tawkid).

5. Jika memungkinkan, penulis membandingkan penilaian yang telah diberikan oleh ulama (selain al-Bukhārì) atas seorang perawi yang dinilai dengan istilah di atas. Penilaian-penilaian ulama ini dianalisis sehingga didapati kesimpulan berupa penilaian akhir atas perawi tersebut.

6. Membandingkan hasil akhir dari penelitian dengan metode content analysis dengan kesimpulan dari ulama..

\section{Muqārib al-Ḥadith}

Huruf Ra' pada kata "muqārib al-ḥadith" diberi tanda baca (harakat/syakal) kasrah, dan bisa juga diberi tanda baca fathah (dibaca "muqārab al-hadith). ${ }^{13}$ Perbedaan tanda baca ini tidak mengubah arti, yaitu mendekati sekaligus didekati. ${ }^{14}$ Istilah muqārib al-ḥadith dinilai sebagai penilaian baik (tawthiq) terhadap kualitas seorang perawi. ${ }^{15}$

Istilah muqārib al-hadith menjadi perlu untuk diteliti mengingat alBukhāri menggunakannya dalam aktivitas penilaian perawi hadis tanpa memberikan penjelasan apa maksudnya. Ada dugaan, al-Bukhārì sengaja tidak menjelaskannya sebagai stimulus kepada generasi selanjutnya untuk menganalisisnya (?).

13 Al-'Irāqi menyatakan bahwa bacaan yang didengarnya hanya berupa "muqārib" yaitu dengan tanda baca kasrah, tidak dengan fahtah.

14 Muqārab mengikuti pola atau wazan "mufāalah" yang dalam ilmu Sarf memiliki faedah "mushārakah" di mana ada dua orang atau dua pihak yang melakukan satu aktivitas yang sama bersama-sama. Pola ini menghendaki bahwa "fá'il" dan "maf'ül" melakukan hal yang sama, sehingga dalam pemaknaannya tidak perlu diberikan distingsi (pembedaan). "Muqārab" artinya orang yang didekati sekaligus ia mendekati, sementara "muqārib" artinya orang yang mendekati sekaligus ia didekati.

15 Ada sebagian ulama semisal Ibn al-Sayyid yang membedakan di mana "muqārib" dipahami sebagai ungkapan "ta' dil" sementara "muqārab" dipahami sebagai ungkapan "jarh". Pendapat ini didasari perbedaan pola/wazan yang ada di tanda baca/harakat/syakal pada huruf Ra'. Namun pendapat ini lemah dan tidak diikuti oleh para kritikus hadis.

'Abdurraḥmān bin Abu Bakr al-Suyuṭị, Tadrīb al-Rāwīi (Dār al-Ṭaybah, ttp, tth.), 411. 
Berikut tabel analisis makna dari istilah muqārib al-hadith: ${ }^{16}$

\begin{tabular}{|c|c|c|c|}
\hline No & Nama Perawi & Ungkapan al-Bukhāri & Penjelasan Tambahan \\
\hline 1 & عبد الهه بن محمد بن عقيل & 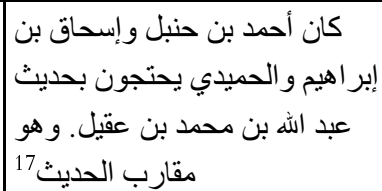 & تكلم فيه بعض الترمذي: هو صدو العلم من قبل وقد \\
\hline 2 & $\begin{array}{l}\text { عبد الرحمن بن زياد بن الإفريقي } \\
\text { النعم }\end{array}$ & هو مقارب الحديث 19 & 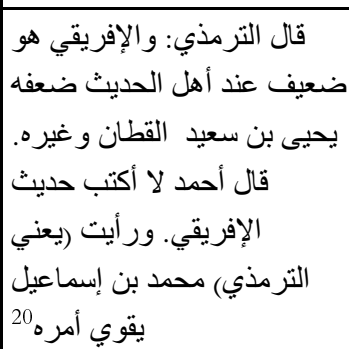 \\
\hline 3 & أبو ظلال & هو مقارب الحديث و اسمه هلال21 & قال الترمذي: هذا حديث حسن \\
\hline 4 & بكار بن عبد العزيز & - & 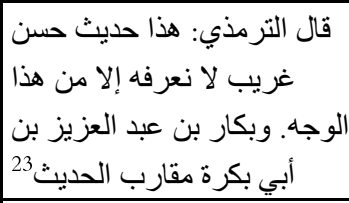 \\
\hline 5 & الوليد بن رباح & رباح سمع من أبي هريخ و والوليد بن وهو & قال الترمذي: هذا حديث حسن \\
\hline
\end{tabular}

${ }^{16}$ Penulis menggunakan data dari kitab Sunan al-Tirmidhi dengan pertimbangan bahwa al-Tirmidhi merupakan murid langsung dari al-Bukhāri dan banyak menggunakan pendapat al-Bukhārì dalam menjelaskan 'ilal (sebab kedhaifan) hadis. Al-Bukhāri sendiri cenderung tidak banyak mengomentari perawi yang dinilainya thiqah. Sebagaimana disebutkan sebelumnya, dugaan kuat terkait makna muqārib al-hadith adalah bahwa istilah ini digunakan untuk perawi yang thiqah, sehingga bisa dimaklumi jika istilah ini tidak kita dapati di kitab yang ditulis langsung oleh al-Bukhāri semisal al-Tārikh alKabirr.

${ }^{17}$ Muhammad bin $\bar{T}$ sā al-Tirmidhī, Sunan al-Tirmidhī (Mesir: Shirkah Maktabah wa Maţba'ah Muștfā al-Bāb al-Ḥalabī, 1975), cet. II, vol. I, 8.

${ }^{18}$ Al-Tirmidhi, Sunan al-Tirmidhi, vol. I, 8.

${ }^{19}$ Al-Tirmidhi, Sunan al-Tirmidhī,vol. I, 383.

${ }^{20}$ Al-Tirmidhi, Sunan al-Tirmidhỉ,vol. I, 383.

${ }^{21}$ Al-Tirmidhì, Sunan al-Tirmidhỉ,vol. II, 481.

22 Al-Tirmidhī, Sunan al-Tirmidhī,vol. II, 481.

${ }^{23}$ Al-Tirmidhì, Sunan al-Tirmidhī,vol. IV, 141.

${ }^{24}$ Al-Tirmidhi, Sunan al-Tirmidhï,vol. IV, 141.

25 Al-Tirmidhì, Sunan al-Tirmidhī,vol. IV, 141. 


\begin{tabular}{|c|c|c|c|}
\hline No & Nama Perawi & Ungkapan al-Bukhāri & Penjelasan Tambahan \\
\hline 6 & إسماعيل بن رافع & هو ثقة مقارب الحديث 26 & 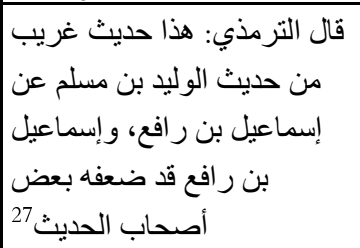 \\
\hline 7 & سيف بن هارون & مقارب الحديث 28 & قال الترمذي: هذا حديث \\
\hline 8 & الجر اح بن الضحاك & مقارب الحديث 30 & قال الترمذي: هذا الحديث إسناده \\
\hline 9 & أبو حمزة (الثمالي) & أحمد بن حنبل تكلم فيه و هو عندي & قال الترمذي: هذا حديث حسن \\
\hline 10 & أبو فروة الرهاوي (يزيد بن & مقارب الحديث إلا أن ابنه محمد & قال الترمذي: هذا حديث حسن 35 \\
\hline 11 & عمر بن هارون & 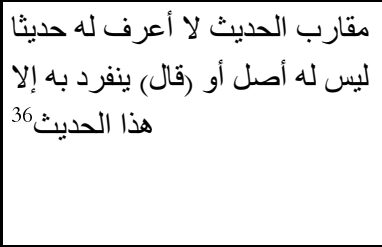 & 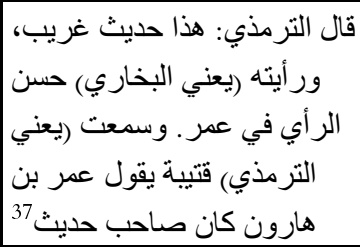 \\
\hline 12 & حجاج بن دينار & ثقة مقارب الحديث 38 & قال الترمذي: هذا حديث حسن 39 \\
\hline
\end{tabular}

Al-Bukhārì menyatakan penilaiannya terhadap perawi dengan ungkapan "muqārib al-hadith", dengan ada sedikit tambahan penjelasan berupa:

1. "Beberapa imam hadis berhujjah dengan perawi ini"

${ }^{26}$ Al-Tirmidhì, Sunan al-Tirmidhī,vol. IV, 189.

${ }^{27}$ Al-Tirmidhì, Sunan al-Tirmidhī,vol. IV, 189.

${ }^{28}$ Al-Tirmidhi, Sunan al-Tirmidhï,vol. IV, 220.

${ }^{29}$ Al-Tirmidhi, Sunan al-Tirmidhi, vol. IV, 220.

${ }^{30}$ Al-Tirmidhi, Sunan al-Tirmidhi, vol. IV, 262.

${ }^{31}$ Al-Tirmidhi, Sunan al-Tirmidhï,vol. IV, 262.

${ }^{32}$ Al-Tirmidhi, Sunan al-Tirmidhï,vol. IV, 279.

33 Al-Tirmidhi, Sunan al-Tirmidhï,vol. IV, 279.

${ }^{34}$ Al-Tirmidhi, Sunan al-Tirmidhi, vol. V, 56.

${ }^{35}$ Al-Tirmidhi, Sunan al-Tirmidhï,vol. V, 56.

${ }^{36}$ Al-Tirmidhi, Sunan al-Tirmidhì,vol. V, 94.

${ }^{37}$ Al-Tirmidhì, Sunan al-Tirmidhì,vol. V, 94.

${ }^{38}$ Al-Tirmidhi, Sunan al-Tirmidhì,vol. V, 378.

${ }^{39}$ Al-Tirmidhì, Sunan al-Tirmidhī,vol. V, 378. 
2. Dua kali al-Bukhāri menambah keterangan thiqah pada perawi yang dinilainya muqārib al-ḥadith.

3. "Hadha ḥadith șahịị"

4. "Nama asli fulan adalah..." "fulan mendengar dari..."

5. "Imam Ahmad membicarakan tentangnya" (menyebut ada perbedaan ulama tentang kualitas perawi tersebut)

6. "Anak perawi ini meriwayatkan banyak hadis munkar darinya"

7. "Perawi ini sendirian dalam meriwayatkan hadis ini"

8. Ada satu kali di mana al-Bukhārì tidak mengomentari seorang perawi namun al-Tirmidhỉ menilainya muqārib al-hadith. Penilaian al-Tirmidhi ini bisa dipastikan berasal al-Bukhārì.

Dari data di atas, bisa disimpulkan bahwa muqārib al-ḥadith menurut alBukhärì adalah perawi thiqah yang periwayatannya shahih namun ada ulama yang mempermasalahkan penilaian thiqah ini. Al-Bukhārī secara implisit menafikan pemaknaan muqārib al-hadith sebagai perawi yang kualitasnya dhaif.

Apa alasan orang yang mempermasalahkan ke-thiqah-an perawi muqārib al-ḥadith? Kita bisa menduga kuat jawabannya melalui penjelasan yang diberikan oleh al-Tirmidhi berikut ini:

1. Bahwa perawi muqārib al-ḥadith disebutkan diperdebatkan ke-thiqah-an dan kedhaifannya oleh ulama (takallam fỉhi al- 'ulamā/da'afahu ba'd aṣhab al-hadith)

2. Dijelaskan bahwa objek perdebatan dan perbedaan pendapat di kalangan nuqqād adalah pada sisi ḍabṭ perawi (min qibal hifzihi/isnāduhu laysa bi dhālik al-qawiy), bukan sisi 'adalah-nya

3. Al-Tirmidhī menilai muqāarib sebagai perawi yang șadūq. penilaian șadūq diberikan kepada perawi yang kualitas dabț-nya di bawah shahih namun di atas dhaif. Sebagian ulama secara simplifikasi menilai hadis yang diriwayatkan oleh perawi dengan penilaian hasan.

4. Walaupun ada sebagian nuqqād yang menilai dhaif, namun al-Bukhārī menilainya baik (hasan al-ra'y/yuqawwi amrhu). Ungkapan seperti ini lumrah kita dapati pada bab hasan li ghayrihi dan șahịh li ghayrihi. ${ }^{40}$

5. Perawi yang muqārib al-ḥadith periwayatannya dinilai hasan ketika ia hanya memiliki satu jalur sanad (gharib)

40 Ḥasan li ghayrihi adalah kualitas dhaif yang meningkat menjadi hasan karena ada penguat eksternal berupa adanya jalur periwayatan lain. Sementara sementara sahị li ghayrihi adalah hadis hasan yang kualitasnya meningkat menjadi shahih karena ada jalur periwayatan lain yang mendukung dan menguatkannya. 
6. Empat kali al-Tirmidhỉ menyatakan hasan-gharīb, yang artinya kualitas perawi ini hasan ketika ia meriwayatkan hadis sendirian.

7. Al-Tirmidhi sekali menyebut hadis yang diriwayatkan oleh muqārib alhadith sebagai hadis yang kualitasnya hasan-sahịh. Dalam penelitian penulis, hasan-sahīh adalah kualitas hadis yang oleh umumnya peneliti hadis disebut dengan sạịih li ghayrihi.

Berdasarkan analisis dari ungkapan-ungkapan yang dinyatakan oleh alBukhārī dan al-Tirmidhì, bisa disimpulkan bahwa muqārib al-ḥadith adalah kualitas setara hasan (kualitas perawinya sadūq), yang bisa meningkat kualitasnya menjadi hasan-sahịh jika periwayatan hadisnya tidak gharib alias ada lebih dari satu jalur. Namun jika periwayatan muqārib al-hadith berbeda dan bertentangan dengan periwayatan yang lebih kuat (asahh) maka pada saat itulah kualitasnya turun menjadi shadh dan menjadi dhaif.

Dengan membaca ungkapan-ungkapan yang menyertai istilah muqārib al-hadith yang dinyatakan oleh al-Bukhārī dan al-Tirmidhì, penulis simpulkan bahwa muqārib al-ḥadith adalah ucapan tawthīq/ta'dil yang menerangkan kualitas setara istilah hasan. Selanjutnya, kesimpulan ini kita komparasikan dengan kesimpulan yang telah dinyatakan oleh para ulama.

Ibn Jama'ah al-Kannānī (w. 733 H.) Ibn al-Jazari, al-Bulqīnì, dan alQastalānī memasukkan muqārib al-ḥadith dalam ungkapan jarh, di level yang sama dengan ungkapan layn al-hadith, yang artinya bahwa istilah ini bermakna mengandung makna dhaif. ${ }^{41}$

Namun pendapat yang popular yang diikuti oleh mayoritas ulama hadis semisal al-'Irāqi, al-Dhahabī, al-Zarkashi, al-Sakhāwī, dan Ibn al-Jawzīi, mengategorikan muqārib al-hadith dalam kelompok ungkapan al-ta'dil bahwa hadis atau periwayatannya dekat dengan periwayatan orang-orang yang thiqah (ann hadithahu yaqrub min hadith al-thiqāt). ${ }^{42}$ Hal ini sama dengan hasil analisis yang penulis sebagaimana disebutkan di atas.

\section{Munkar al-Hadith}

Munkar al-hadith merupakan istilah yang dikenal secara umum oleh para pemerhati dan pengkaji hadis. Setiap buku atau literatur tentang ilmu hadis bisa dipastikan memuat penjabaran tentang terminologi munkar al-hadith. ${ }^{43}$

\footnotetext{
41 Muhammad bin Ibrāhīm bin Sa'dillāh bin Jama'ah, al-Manhal al-Rāwī fí Mukhtasar 'Ulüm al-Hadith al-Nabawì (Damaskus: Dār al-Fikr, 1406 H.), cet. II., 65.

${ }^{42}$ Al-Sakhāwì, Fatḥ al-Mughïth, vol. II, 119.

43 Ada beberapa istilah lain yang terkait dengan munkar al-hadith, yaitu: Nakārah, tafarrud, mukhālafah, shādh, ma'rūf, mahfūz, manakỉr, dan lā yutāba'.
} 
Umumnya, perawi munkar dipahami sebagai perawi yang dhaif yang periwayatannya bertentangan dengan periwayatan orang yang thiqah. ${ }^{44}$ Sementara hadis munkar adalah hadis yang di dalam mata rantai sanadnya ada perawi yang kualitasnya munkar.

Apakah al-Bukhāri menggunakan istilah munkar al-ḥadith sebagaimana pemaknaan umum di atas? Untuk menjawab pertanyaan ini kita coba analisis ungkapan yang menyertai istilah munkar al-hadith dan perawi yang dalam kitab al-Tärikh al-Kabïr dinilai oleh al-Bukhāri sebagai munkar al-ḥadith.

Di dalam kitab al-Tärikh al-Kabìr, ada sekitar 200 perawi yang dinilai munkar al-hadith, sebagian kecil di antara diberi keterangan tambahan berupa:

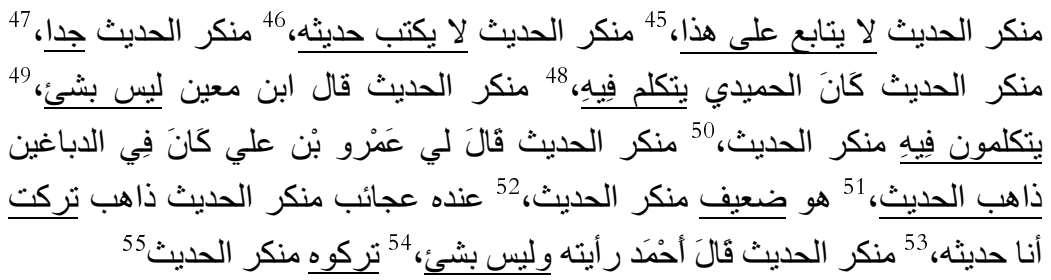

Berdasarkan pembacaan terhadap ungkapan-ungkapan penjelas di atas, dapat disimpulkan bahwa ulama sepakat bahwa label munkar al-hadith dilekatkan kepada perawi yang dhaif. Bisa disimpulkan juga bahwa penyebab

44 Dalam “muqaddimah”, Muslim bin al-Ḥajjāj (w. 261 H.) menyatakan bahwa ciri munkar dalam hadis adalah periwayatan yang berbeda dengan periwayatan dari perawi yang thiqah (ahl al-hifz wa al-riḍa).

Muslim bin al-Ḥajjāj al-Naysabūri, "Muqaddimah” dalam Șahịh Muslim (Beirut: Dār Ihỵā al-Turāth al-'Arabī, tth), vol. I, 6.

Shādh dan munkar al-hadith sama-sama menggambarkan adanya perbedaan periwayatan antara seorang perawi dengan perawi yang lain terkait hadis yang sama. Distingsi di antara keduanya adalah bahwa perawi shādh itu thiqah yang berbeda periwayatannya dengan dengan periwayatan perawi lain yang lebih thiqah, sementara munkar al-hadith itu perawi dhaif yang berbeda periwayatannya dengan perawi thiqah. Penyebab kedhaifan shādh ada di sisi ḍab̄ saja, sementara penyebab kedhaifan munkar al-hadith ada di sisi ḍabt dan 'adalahnya. Dari sini bisa dimengerti jika kualitas munkar al-ḥadith lebih rendah dari shādh.

${ }^{45}$ Al-Bukhārī, al-Tärīkh al-Kabìr, vol. I, 37.

${ }^{46}$ Al-Bukhāri, al-Tärīkh al-Kabīir, vol. I, 88.

${ }^{47}$ Al-Bukhārì, al-Tärīkh al-Kabìr, vol. VIII, 384.

${ }^{48}$ Al-Bukhāri, al-Tärīkh al-Kabìr, vol. I, 163.

${ }^{49}$ Al-Bukhārì, al-Tārikh al-Kabīr, vol. I, 171.

${ }^{50}$ Al-Bukhārì, al-Tārìkh al-Kabìr, vol. I, 202.

${ }^{51}$ Al-Bukhārī, al-Tārikh al-Kabìr, vol. I, 218.

${ }^{52}$ Al-Bukhāìi, al-Tärikh al-Kabìr, vol. II, 189.

${ }^{53}$ Al-Bukhārì, al-Tärỉkh al-Kabìr, vol. II, 343.

${ }^{54}$ Al-Bukhāri, al-Tärīkh al-Kabìr, vol. III, 244.

${ }^{55}$ Al-Bukhāri, al-Tärìkh al-Kabìr, vol. II, 345. 
kedhaifan munkar al-hadith ada di sisi ḍabṭ dan 'adālah. Selanjutnya boleh kita nyatakan bahwa perawi-perawi yang dinilai munkar al-hadith berbeda-beda tingkat kedhaifannya, di mana yang paling tinggi adalah dhaif yang masih diperselisihkan kedhaifannya dan yang paling rendah adalah perawi yang disepakati oleh ulama sebagai perawi matrūk $\left(\operatorname{tarakuhhu).}{ }^{56}\right.$ Al-Bukhārì sendiri sudah menegaskan bahwa seluruh perawi yang dinilainya munkar al-hadith itu tidak bisa dijadikan hujjah dan tidak halal diriwayatkan semua periwayatannya. $^{57}$

Selanjutnya, kita perbandingkan penilaian al-Bukhāri dengan penilaian ulama lain terhadap seorang perawi yang dilabeli munkar al-hadith.

Muhammad bin Zādhān dinilai oleh al-Bukhārì sebagai perawi munkar al-ḥadith lā yuktab ḥadithuhu, ${ }^{58}$ sementara Abū Ḥātim menilainya matrūk alhadith lā yuktab 'anh, ${ }^{59}$ al-Tirmidhì menilainya munkar dan al-Dāruquthnì menilainya dhaif. ${ }^{60}$

Berdasarkan pembacaan atas penilaian ulama terhadap Muhammad bin Zādhān, disimpulkan bahwa para ulama sepakat mengenai munkar al-hadith sebagai perawi yang kualitasnya dhaif, namun mereka berbeda pendapat terkait kadar atau tingkat kedhaifannya. Dapatlah dimaklumi bahwa ulama belakangan (mutaakhiriin) berbeda pendapat terkait maksud dari al-Bukhārì terkait istlah munkar al-hadith yang digunakannya. ${ }^{61}$

\section{Sukūt al-Bukhārì}

Diamnya seseorang, atau sukūt, bisa diartikan ia tidak tahu, atau ia tidak mau mengomentari, dan bisa juga dipahami bahwa ia sedang memberikan penilaian melalui diamnya itu.

${ }^{56}$ Matrūk disebut juga semi palsu, adalah perawi yang biasa berbohong namun belum terbukti memalsukan hadis. Orang yang dinilai matrūk dan pemalsu hadis samasama ditolak periwayatannya.

${ }^{57}$ Al-Sakhāwīi, Fatḥ al-Mughīth,vol. II, 130, al-Suyūț, Tadrīb al-Rāqī, 410.

${ }^{58}$ Muḥammad bin Ismā'il al-Bukhāri, al-Tärikh al-Kabìr (Hedarabad: Dār alMa'ārif al-'Uthmāniyyah, tth.), al-Tärikh al-Kabìr, vol. I, 88.

59 'Abdurraḥmān bin Abì Hāatim, al-Jarḥ wa al-Ta'dìl (Hedarabad: Majlis Dāirah al-Ma'ārif al-'Uthmāniyyah, 1952), cet. I, vol. VII, 260.

${ }^{60}$ Muhammad bin Ahmad al-Dhahabịi, Mízān al-I'tidāl fì Naqd al-Rijāl (Beirut: Dār al-Ma'rifah, 1963), cet. I, vol. III, 546.

${ }^{61}$ Ketika mengomentari Sulaymān bin Binti Șuraḥbìl, al-Dāruquthnī menilainya thiqah, sementara ulama lain menilainya munkar al-ḥadith. Ketika ditanya lebih lanjut, beliau menjawab bahwa Sulaymān sejatinya adalah perawi thiqah hanya saja ia banyak menerima periwayatan dari orang yang dhaif.

Al-Sakhāwī, Fatḥ al-Mughìth, vol. II, 130. 
Al-Bukhāri dikenal sebagai tokoh yang sangat mengetahui biografi perawi-perawi hadis. Penilaian beliau terhadap seorang perawi dikutip dan diikuti oleh kritikus hadis setelahnya. Dalam kisah yang popular di kalangan pengkaji hadis, disebutkan bahwa Muslim bin al-Ḥajjāj pernah sedemikian menggebu-gebu bertanya kepada al-Bukhārì tentang kedhaifan hadis "doa kaffarah majelis". ${ }^{2}$ Al-Bukhārī juga dijadikan panutan utama oleh Muslim dan dibelanya dengan gigih ketika ia ditegur dengan keras oleh Muhammad bin Yahyā al-Dhuhli dalam perdebatan masalah "khalq al-Qurān". Rasanya janggal ketika al-Bukhārì berdiam diri tidak memberikan penilaian terhadap perawiperawi hadis yang sedang dia jelaskan biografinya dengan dugaan bahwa ia hal itu dilakukan akibat ketidaktahuan. Maka, asumsi yang kuat adalah bahwa alBukhārì menjadi diamnya itu sebagai salah satu bentuk penilaian atas kualitas perawi hadis.

Dalam kitab al-Târìkh al-Kabîr, ada lebih 20 perawi yang dinilai dengan ungkapan "sakatū 'anh" yang artinya para ulama mendiamkan dan tidak memberikan penilaian atas perawi ini. Berikut ungkapan yang digunakan alBukhāri saat mengomentari perawi-perawi tersebut:

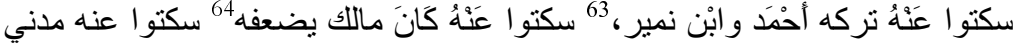

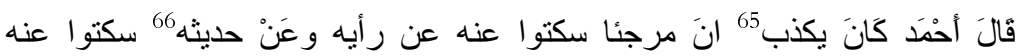

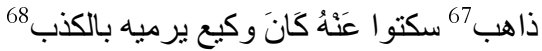

Dengan membaca keterangan tambahan di atas, bisa disimpulkan bahwa istilah sakatū 'anhu diberikan oleh al-Bukhāri kepada perawi hadis yang kualitasnya sangat dhaif, yaitu perawi yang seluruh hadisnya ditolak (dhāhib), matrūk, dan mawḍù' (palsu).

Kesimpulan di atas selaras dengan apa yang dinyatakan oleh Ibn Kathīr (w. 774 H.) "fì adnā al-manāzil wa ardaihā 'indahu" (tingkat paling rendah dan paling hina).69 Al-Suyūṭi mengategorikan sakatū 'anhu satu tingkat di atas

${ }^{62}$ Selain menulis kitab Șahịh Muslim, Muslim dikenal sebagai pakar ilmu 'ilal hadith dimana kitab al-Tamyiz yang ditulisnya menjadi rujukan utama oleh kritikus hadis

${ }^{63}$ Al-Bukhārì, al-Tārikh al-Kabìr, vol. I, 178.

${ }^{64}$ Al-Bukhārì, al-Tārikh al-Kabìr, vol. V, 96.

${ }^{65}$ Al-Bukhārì, al-Tärīkh al-Kabìr, vol. VII, 164.

${ }^{66}$ Al-Bukhāri, al-Tärikh al-Kabìir, vol. VIII, 81.

${ }^{67}$ Al-Bukhāīi, al-Tärīkh al-Kabìr, vol. VIII, 105.

${ }^{68}$ Al-Bukhāri, al-Tärikh al-Kabìr, vol. VIII, 170.

${ }^{69}$ Ibnu Kathìr, Ikhtișār 'Ulūm al-Hadith, 106. 
pemalsu hadis. ${ }^{70}$ Al-Sahkāwi bahkan menggolongkan sakatū 'anhu setara dengan kadhdhāb alias orang yang sangat sering memalsukan hadis. ${ }^{71}$

\section{Penutup}

Metodologi content analysis bisa menjadi alternatif yang baik untuk meneliti istilah-istilah ilmiah yang belum diketahui maksudnya, atau yang maksudnya sudah dijelaskan oleh para pakar namun masih mengundang perdebatan di kalangan mereka sendiri. Metode content analysis bisa digunakan secara luas, bukan saja di korpus ilmu hadis, namun juga di ilmu tafsir dan ilmuilmu keislaman lainnya.

Allah A 'lam

\section{Daftar Bacaan}

Azami, MM (Muḥammad Muștafa al-A'zamī). Manhaj al-Naqd 'Inda alMuhaddithīn. Saudi Arabia: Maktabah al-Kawthar, 1990, cet. III.

Al-Bukhāri, Muhammad bin Ismāīil. al-Tārīkh al-Kabìr. Hedarabad: Dār alMa'ārif al-'Uthmāniyyah, tth.

Burke, Peter. History and Social Theory. Alih bahasa oleh Mestika Zed dan Zulfahmi. Sejarah dan Teori Sosial. Jakarta: Yayasan Pustaka Obor Indonesia, 2011, cet. III.

Al-Dhahabi, Muḥammad bin Aḥmad. Mizān al-I'tidāl fỉ Naqd al-Rijāl. Beirut: Dār al-Ma'rifah, 1963, cet. I

Ibnu Abỉ Ḥātim, 'Abdurraḥmān. al-Jarḥ wa al-Ta'dỉl. Hedarabad: Majlis Dāirah al-Ma'ārif al-'Uthmāniyyah, 1952, cet. I.

Ibn al-Jawzì, 'Abdurraḥmān bin 'Ali bin Muhammad. al-Mawḍu'àt. Madinah: al-Maktabah al-Salafiyah, 1968, cet. I.

Ibnu Jama'ah, Muḥammad bin Ibrāhīm bin Sa'dillāh. al-Manhal al-Rāwī fí Mukhtasar 'Ulüm al-Hadith al-Nabawì. Damaskus: Dār al-Fikr, 1406 H. cet. II.

Ibn Kathīr, Ismaì'îl bin 'Umar. Ikhtișār 'Ulūm al-Hadith. Beirut: Dār al-Kutub al-'Ilmiah, tth., cet. II.

Krippendorff, Klaus. Content Analysis: An Introduction to Its Methodology. London: Sage Publications Ltd, 2004.

${ }^{70}$ Al-Suyūțī, Tadrīb al-Rāwī, 409.

${ }^{71}$ Al-Sakhāwì, Fath al-Mughīth, vol. II, 126. 
Al-Naysābūrī, Muslim bin al-Ḥajjāj. "Muqaddimah." Dalam Șahịḥ Muslim. Beirut: Dār Ihyāa al-Turāth al-'Arabī, tth.

Rahman, Andi. "Arus Utama Diskursus Hadis: Kajian Atas Otentisitas dan Otoritasnya Sebagai Hujjah.” Dalam Jurnal al-Burhan, vol. 16, no. 1 (2011).

Al-Sakhāwi, Muḥammad bin 'Abdurraḥmān. Fatḥ al-Mughīth. Kairo: Maktabah al-Sunnah, 2003, cet. I.

Al-Suyūṭ̂i, 'Abdurraḥmān bin Abu Bakr. Tadrīib al-Rāwīi. Dār al-Ṭaybah, ttp, tth.

Al-Tahāâwi, Ahmad bin Muhammad. Sharh Mushkil al-Āthār. Muassasah alRisālah, ttp, 1494, cet. I.

Al-Ṭaḥhān, Maḥmūd. Taysīr Muṣtalạ̣ al-Hadith. Iskandariya: Markaz al-Hudā li al-Dirāsāt, 1415 H, cet. VII.

Al-Tirmidhī, Muhammad bin '̄isā. Sunan al-Tirmidhī. Kairo: Shirkah Maktabah wa Maṭba'ah Muṣtfāa al-Bāb al-Ḥalabī, 1975, cet. II. 